\title{
O INWENTARZU PRZYPADKÓW W PIERWSZYCH GRAMATYKACH JĘZYKA FIŃSKIEGO
}

\author{
ANNA BUNCLER \\ Uniwersytet Warszawski \\ a.buncler@uw.edu.pl
}

The inventory of cases in the first Finnish grammars

The article deals with the formulation of the inventory of cases in the earliest Finnish grammars. Finnish language as a Finno-Ugric one differs typologically from Indo-European languages among others in regard of case system - there are 14-15 different case markers to be distinguished. In the first Finnish grammars however their authors [Petraeus 1649, Martinius 1689] followed the Latin pattern of six cases by choosing semantically or syntactically coherent cases. Therefore for example the ending of partitive was assigned to two different cases (nominative, accusative), non existing vocative was identical with nominative, and on the other hand ablative had four different endings. The first grammars didn't also make a difference between word stem and ending. In the third Finnish grammar [Vhael 1733] the inventory of cases is already much larger and it consists of 14 cases. The first ones still reflect Latin cases but from the nowadays perspective only comitative is missing. Vhael didn't however perceive a system of locative cases. Von Becker [1824] also distinguishes 14 cases but is atready able to divide them on the basis of their locative meaning into dativus, locativus, ablativus on the one hand and exterior, interior, formalis on the other. The inventory of Finnish cases similar to the one used today can be seen in Renvall's grammar [1840] although there are still slight differences in the names of the cases.

Keywords: grammar, case, inventory of cases, Finnish language

Avainsanat: kielioppi, sijamuoto, sijaluettelo, suomen kieli

Słowa kluczowe: gramatyka, przypadek, inwentarz przypadków, język fiński 
W języku fińskim - jako aglutynacyjnym - istnieje wiele sufiksów, którym można przypisać status przypadka. We współczesnych gramatykach opisowych wyróżnia się 14-15 wykładników tej kategorii gramatycznej. Również inne języki ugrofińskie posiadają rozbudowane systemy przypadkowe ${ }^{1}$. Celem tego artykułu nie jest sprawdzenie adekwatności przyjętego w gramatykach wzorca do rzeczywistości języka fińskiego, lecz jedynie ukazanie, jak rzeczywistość tę usiłowano wtłoczyć do modelu wypracowanego dla innych, odmiennych typologicznie języków. Odmienność struktury języka fińskiego na tle wzorca grecko-łacińskiego oraz ogólniej języków indoeuropejskich stała się bowiem trudnością w opisie systemu przypadkowego. Dokonam zatem przeglądu inwentarzy przypadków w pierwszych gramatykach języka fińskiego oraz przyjrzę się problemom metodologicznym związanym z kształtowaniem zbioru tej kategorii gramatycznej [por. Buncler 2004].

Pierwsza wzmianka o próbie stworzenia gramatyki języka fińskiego pochodzi z 1579 roku. Jej twórcą miał być uczeń kolegium jezuickiego w Ołomuńcu, Fin Olaus Sundergelteus, a służyć miała ona celom kontrreformacji, a dokładniej przetłumaczeniu na język fiński katechizmu katolickiego [Vihonen 1978: 28]. Zgromadzenie stanowe w Uppsali w 1593 roku uznało jednak za religię dominującą luteranizm, co zahamowało działania na rzecz kontrreformacji w Szwecji i w Finlandii, a tym samym najprawdopodobniej zniweczyło plany opracowania gramatyki fińskiej, o której brak dalszych wzmianek.

Pierwszą obszerniejszą, i najprawdopodobniej gruntownie opracowaną, gramatyką języka fińskiego było dzieło Henryka Crugerusa, wikariusza w Naantali, powstałe około 1640 roku, które nie zachowało się do naszych czasów [Häkkinen 1994: 104-105]. Jego rękopis krążył w XVII wieku po Danii i został wykorzystany przez tamtejszych gramatyków - Erika Pontoppidan oraz Pedra Syv. Z ich wzmianek dotyczących języka fińskiego można wywnioskować, że praca Crugerusa zawierała ortografię, morfologię i składnię. Syv podaje, że w języku fińskim występuje 12 przypadków, a wiedza ta opierała się zapewne na rękopisie Crugerusa, którego istnienie Syv potwierdza dwukrotnie. Niestety nie podaje żadnych przykładów [Vihonen 1978: 29]. Już sam fakt wzmiankowania rozbudowanego inwentarza przypadków wskazuje na to, że gramatyka Crugerusa była przedsięwzięciem innowacyjnym,

\footnotetext{
$1 \mathrm{~W}$ prajęzyku uralskim występowało jednak hipotetycznie 6-7 wykładników przypadka liczba ta systematycznie się powiększała w trakcie rozwoju takich języków, jak m. in. język fiński i węgierski. Sprzyjała temu aglutynacyjna struktura obu tych języków przejawiająca się m. in. w kombinacji sufiksów już istniejących, a także dążenie do coraz większej specjalizacji poszczególnych wykładników, zwłaszcza w wyrażaniu lokatywności [por. Buncler 2012].
} 
znacznie wyprzedzającym metodologicznie późniejsze gramatyki XVII-wieczne, lecz prawdopodobnie z tego powodu trudnym w odbiorze dla ówczesnego czytelnika.

Kolejne gramatyki, autorstwa Eskila Petraeusa i Matthiasa Martiniusa, miały służyć jako podręczniki do nauki języka fińskiego dla obcokrajowców, funkcjonowały zatem na gruncie tradycji starożytnej - greckiej i łacińskiej, co było uzasadnione ich przeznaczeniem. Najstarsza zachowana gramatyka, wydana drukiem w 1649 roku Linguae Finnicae brevis institutio, przypisywana powszechnie Petraeusowi, mimo że jej współtwórcami byli także Gregorius Favorinus i Martin Stodius, została opracowana, jak podaje sam Petraeus w przedmowie, na rozkaz generała-gubernatora Piotra Brahe z przeznaczeniem dla „tych Szwedów, Niemców, Szkotów i innych obcokrajowców”, którzy chcieli mówić poprawnie po fińsku [Vihonen 1978: 29]. Była zatem adresowana przede wszystkim do odbiorców władających biegle łaciną i wychowanych w łacińskim systemie edukacji, a przekazywać miała prawidła obcego, dziwnego (bo innego typologicznie) języka, który poprzez dostosowanie go do wzorca gramatyki łacińskiej miał się stać bardziej zrozumiały i przystępny. Gramatyka Petraeusa wyprzedziła o 47 lat pierwszą gramatykę języka szwedzkiego, co wynikało właśnie z zapotrzebowania na elementarz do nauki fińskiego. W połowie XVII wieku Szwecja prowadziła wzmożoną politykę zjednoczeniową, wysyłając na ważniejsze urzędy w Finlandii swoich szwedzkich podwładnych, których uważano za bardziej godnych zaufania. W ten sposób chciano zapobiec nawrotowi kryzysu, który nastąpił pod koniec XVI wieku, kiedy to Finlandia na pewien czas odłączyła się od Szwecji [Vihonen 1978: 29]. Sam Petraeus był z urodzenia Szwedem, a opracowując swoją gramatykę korzystał z pomocy członków komitetu do spraw przekładu Biblii, którego był przewodniczącym [Häkkinen 1994: 105-106].

W 1689 ukazała się w Sztokholmie druga gramatyka języka fińskiego Hodegus Finnicus, Eller Finsk Wägwijsare, autorstwa Martiniusa, lektora liceum w Wyborgu, napisana najprawdopodobniej na życzenie ówczesnych wielmoży - Johana Bergenhjelma, Johana Schmedemanna i Johana Paulinusa [Vihonen 1978: 31]. Martinius w wielu punktach powielił gramatykę Petraeusa ${ }^{2}$. Zjawisko to było dość częste w owych czasach: pisanie gramatyk traktowano inaczej niż uprawianie twórczości literackiej, która stanowiła o indywidualności autora.

\footnotetext{
${ }^{2}$ Hodegus Finnicus jest jednak obszerniejsza od gramatyki Petraeusa, zawiera dokładniejsze objaśnienia dotyczące fonetyki i więcej przykładów z języka potocznego (nie bazuje jedynie na bezpośrednich tłumaczeniach z łaciny, na których przede wszystkim opierał się Petraeus), a także objaśnienia szwedzkojęzyczne [Häkkinen 1994: 106].
} 
Twórcy gramatyk przedstawiali natomiast własności języka według wytyczonego wcześniej wzorca, przyjmowanego jako uniwersalny, który powielali na użytek danego języka, a nawet stosowali dosłowne powtórzenia. Dopiero kiedy łacina utraciła status uniwersalnego języka nauki, prace wczesnych gramatyków zaczęto postrzegać jako plagiaty [Vihonen 1978: 37-38].

Część badaczy uważała, że wzorem dla Petraeusa była estońska gramatyka Henryka Stahla [Vihonen 1978: 32], wydana 12 lat wcześniej w 1637 roku. Nordman wykazał jednak, że między obydwoma pracami istnieją zbyt wyraźne rozbieżności, by można było mówić o bezpośrednim wpływie gramatyki Stahla na Linguae Finnicae. Jego zdaniem za pierwowzór należałoby uznać łacińską gramatykę Chytraeusa, na co wskazują zapożyczenia terminologiczne i identyczność sformułowania większości reguł [Vihonen 1978: 34]. Petraeus, który studiował w Wittemberdze i Jenie, był na pewno dobrze zaznajomiony $\mathrm{z}$ łacińskimi gramatykami Donatusa, Chytraeusa, Tiderusa oraz Melanchtona, wykorzystywanymi zresztą w Szwecji jako podręczniki do nauki łaciny na poziomie elementarnym [Leiwo, Nieminen 2000: 418]. Z tego względu sporo badaczy twierdzi, że to one właśnie stanowiły bezpośredni wzór dla Petraeusa.

Wielu językoznawców, patrzących z dzisiejszej perspektywy, uważa, że obie XVI-wieczne gramatyki były dziełami nieudolnymi i niekompetentnymi, próbującymi na siłę wpasować język fiński w nieprzystające do niego kategorie łaciny. Według Sakariego Vihonena taka ocena jest błędna. Nie były to bowiem prace o charakterze naukowym, lecz podręczniki do praktycznej nauki fińskiego dla początkujących obcokrajowców władających łaciną, jedynego języka mogącego pełnić funkcję języka-pośrednika oraz metajęzyka. Funkcjonalne względy zadecydowały o przyjęciu przez autorów konfrontatywnej metody opisu języka, której zadaniem było pokazanie, jak kategorie gramatyki łacińskiej można wyrazić w języku fińskim [Vihonen 1978: 30], jak znaleźć łacińskie odpowiedniki wyrażeń fińskich i tym samym możliwie najszybciej wprowadzić obcokrajowca w tajniki nowego języka. Reszty miał dopełnić „usus quotidianus” [Vihonen 1978: 32].

Pojęcie gramatyki według Petraeusa i Martiniusa pokrywało się zresztą z ówczesnymi wyobrażeniami widocznymi w pracach opisujących strukturę innych języków europejskich, np. angielskiego, niemieckiego, węgierskiego. Termin gramatyka oznaczał łacińską gramatykę, a reguły gramatyczne - reguły gramatyki łacińskiej. System gramatyki łacińskiej miał odzwierciedlać uniwersalne zasady logiki, dające się zastosować w opisie wszystkich języków i funkcjonował jako norma dla tworzenia gramatyk. 
Petraeus w swojej gramatyce uwzględnia 6 przypadków łacińskich: nominativus, genitivus, dativus, accusativus, vocativus i ablativus. Jego klasyfikacja ma uzasadnienie nie tyle morfologiczne, co semantyczne. Taki sam inwentarz przypadków jest zawarty w Hodegus Finnicus Martiniusa. Paradygmat odmiany współczesnych wyrazów palvelija (servus 'sługa') oraz alku (principium 'początek') według Petraeusa wyglądał następująco [za: Leiwo, Nieminen 2000: 417 i Vihonen 1978: 91]:

Tabela 1. Inwentarz przypadków w gramatyce Petraeusa [źródło: oprac. własne]

\begin{tabular}{c|r|r} 
Przypadek & Liczba pojedyncza & Liczba mnoga \\
\hline Nominativus & palwelia \\
alcu & palwelian \\
algun & $\begin{array}{r}\text { paliat } \\
\text { Genitivus }\end{array}$ & $\begin{array}{r}\text { palwelialle } \\
\text { algulle }\end{array}$ \\
palwelioitten \\
Dativus
\end{tabular}

Omawiając kolejne przypadki Petraeus podaje reguły dotyczące tworzenia form accusativu, ablativu oraz nominativu i accusativu w liczbie mnogiej, naśladując w tym Chytraeusa [Vihonen 1978: 89]. Dobiera formy fińskie odpowiadające znaczeniu łacińskich przypadków. Stąd też jeden przypadek może posiadać więcej niż jeden sufiks. Taki stan rzeczy nie jest obcy łacinie, która z racji rozbudowanej deklinacji posiadała różne końcówki (terminatio), pełniące tę samą funkcję semantyczną, z drugiej zaś strony jednej końcówce mogły przysługiwać różne znaczenia [Vihonen 1978: 89-90].

W ujęciu Petraeusa accusativus liczby pojedynczej pokrywał się z dzisiejszym genetivem i partitivem, a accusativus liczby mnogiej odpowiadał dzisiejszemu nominativowi i partitivowi. Podział ten opierał się na funkcji syntaktycznej sufiksów aglutynacyjnych - funkcji przedmiotu - accusativu w łacinie, któremu Petraeus podporządkował odpowiednie formy języka fińskiego. System Petraeusa nie uwzględniał dzisiejszego accusativu liczby pojedynczej, równokształtnego z postacią nominativu, skąd można wnioskować, że nominativus w ujęciu Petraeusa spełniał funkcję obecnego accusativu. Poza 
tym nominativowi w liczbie mnogiej Petraeus przyporządkował formy dzisiejszego partitivu. Poniżej przedstawiam zestawienie ilustrujące wymienione zależności (we współczesnym zapisie).

Tabela 2. Zależności między nominativem, genetivem i accusativem w gramatyce Petraeusa [źródło: oprac. własne]

\begin{tabular}{c|r|r|r|} 
Liczba & $\begin{array}{c}\text { Nomina- } \\
\text { tivus }\end{array}$ & Genetivus & $\begin{array}{c}\text { Accu- } \\
\text { sativus }\end{array}$ \\
\hline poj. & Alku & alun & $\begin{array}{r}\text { Alun } \\
\text { alkua }\end{array}$ \\
\hline mn. & $\begin{array}{r}\text { alut } \\
\text { alkuja }\end{array}$ & & $\begin{array}{r}\text { alut } \\
\text { alkuja }\end{array}$ \\
\cline { 2 - 3 } & &
\end{tabular}

Wzorem Petraeusa Martinius również przyporządkowuje accusativowi po dwa sufiksy w każdej liczbie [Vihonen 1978: 92]. Gramatyka Petraeusa nie formułuje reguł identyfikowania form genetivu, możemy je jednak znaleźć u Martiniusa. Według tego autora formy genetivu w liczbie pojedynczej kończą się na - $n$ (Omnium Declinationum Genitivi singulares desinunt in $N$ ). Potwierdza to przykładami uszeregowanymi według ośmiu paradygmatów deklinacyjnych, które miałyby przysługiwać językowi fińskiemu³ [Vihonen 1978: 92]. Gdyby Martinius znał szerszą interpretację odmiany zawartą w estońskiej gramatyce Stahla, mógłby uznać, że deklinacja jest $w$ języku fińskim pojęciem zbędnym, zmienia się bowiem tylko samogłoska, natomiast spółgłoska pozostaje taka sama. Genetivus liczby pojedynczej posiada więc tylko jeden wykładnik, choć łacina posiada ich wiele.

Ablativus Petraeusa wyrażony jest przez cztery sufiksy, przyporządkowane dzisiejszemu ablativowi (palvelijalta), elativowi (palvelijasta), inessivowi (palvelijassa) oraz adessivowi (palvelijalla). Podstawę takiej systematyzacji dała Petraeusowi nauka Arystotelesa o czterech zasadach wyjaśniania własności rzeczy - tzw. czterech przyczyn (causae), która funkcjonowała w myśli gramatycznej już w średniowieczu, a którą jako pierwszy zastosował w swojej gramatyce Julius Caesar Scalinger

\footnotetext{
${ }^{3}$ Osiem deklinacji języka fińskiego Petraeus wyprowadza z ośmiu różnych zakończeń genetivu w liczbie pojedynczej o postaci samogłoska $+n$, obejmujących wszystkie osiem samogłosek języka fińskiego (odpowiednio: an, än, en, in, on, ön, un, yn, uważane za odrębne wykładniki genetivu) [Vihonen 1978: 93]. Nominativus uważany był za podstawę w tworzeniu deklinacji i od niego miały pochodzić formy genetywne, jak również pozostałe formy przypadków. Taki wzór deklinacyjny był powszechny w pracach pierwszych gramatyków (aż do gramatyki Jacoba Judéna z 1818 roku) i Kalevi Wiik nazywa ten okres „okresem nominativistów" [Leiwo, Nieminen 2000: 418-419]. Pojęcie rdzenia nie było wówczas jeszcze znane.
} 
w 1540 roku [Vihonen 1978: 91]. Cztery zasady Arystotelesa obejmowały: 1) causa materialis (materia), 2) causa formalis (nadająca materii formę), 3) causa efficiens (przyczyna) oraz 4) causa finalis (cel powstający na skutek oddziaływania causa efficiens).

Opisy morfologiczne ablativu różnią się w gramatykach Petraeusa i Martiniusa. Petraeus dokładniej określa granicę między morfemami (nie znając jeszcze podziału na rdzeń i sufiks aglutynacyjny), uznając za wykładniki ablativu lda, ldä, sta, stä, lla, llä, sa, sü. U Martiniusa mają one postać: da, dä, sta, stä, la, lä, sa, sä.

Opisując funkcje semantyczne ablativu Martinius zauważył odpowiedniość między cząstkami przypadka a łacińskimi prepozycjami. I tak, morfem da lub dä oznaczający rei causam efficientem odpowiada znaczeniu łacińskiego przedimka a (Jumalalda / af Gudi / a Deo), morfem sta lub stä komunikujący rei causam materialem odpowiada łacińskiemu e, ex (orjantappuroista / af törne / e spinis, kiwistä / af steenar / ex lapidibus), sufiks la lub lä (instrumentum efficientis) posiada takie samo znaczenie jak łaciński ablativus lub prepozycja cum + ablativus (miecalla / med swärd / gladio, seipäillä / med staffrar / cum fustibus), natomiast morfem sa lub sä zawiera w sobie znaczenie łacińskiego przedimka in + ablativus (leiwäsä / uti bröd) in pane) [Vihonen 1978: 92-93; Vladár 2003: 138]. Martinius zauważa tė̇, że sufiksy sta i stä oznaczają często przyczynę rei causam efficientem podobnie jak da i dä (Pyhästä Hengestä / af then Helge Anda / a Spirtu Sancto, hänestä / af honom / ex ipso). Przytacza tu przykłady z fińskiego przekładu Biblii.

Inwentarz XVII-wiecznych przypadków zawiera - zgodnie z wzorcem łacińskim, również vocativus, równokształtny z nominativem w obydwu liczbach, mimo że vocativus nie należy w ogóle do systemu przypadków w języku fińskim.

Inwentarz przypadków określony przez Petraeusa, w porównaniu ze stanem przyjętym we współczesnych gramatykach języka fińskiego, obejmuje następujące sufiksy aglutynacyjne:

1) nominativus w 1 . poj. i l. mn.,

2) genetivus w 1. poj. i $1 . \mathrm{mn}$.,

3) allativus w 1 . poj i $1 . \mathrm{mn}$.,

4) accusativus w 1. poj i 1. mn. (oprócz accusativu o postaci morfologicznej nominativu w 1. poj.),

5) partitivus w 1. poj. i $1 . \mathrm{mn}$.,

6) ablativus w 1 . poj. i $1 . \mathrm{mn}$.,

7) elativus w 1. poj. i $1 . \mathrm{mn}$.,

8) inessivus w 1. poj. i 1. mn.,

9) adessivus w 1. poj. i $1 . \mathrm{mn}$. 
Nie występują więc w nim dzisiejszy:

10) essivus,

11) translativus,

12) illativus,

13) abessivus,

14) comitativus,

15) instructivus.

Wprawdzie formy te występują w gramatyce Petraeusa, lecz zostały przez niego odmiennie sklasyfikowane i wtłoczone do klasycznego systemu sześciu przypadków charakteryzowanych w ramach składni. Na przykład formy zakończone na na i nä według Petraeusa są wykładnikami nominativu w opisie składniowym [Vihonen 1978: 91], a także ablativu (cotona, päivänä - elativus w znaczeniu lokatywnym i temporalnym) [Vihonen 1978: 179]. Podobnie formy zawierające sufiksy kse i ksi (obecnie kwalifikowane jako translativus) Petraeus uznaje za formy nominativu, np. hän on walittu Cuningaxi 'został wybrany na króla' lub accusativu, np. hän otti duomarixens minun 'on wziął mnie na sędziego'. Natomiast dzisiejszy illativus jest uznany za accusativus, np. w zdaniu hän meni Turcuhun 'udał się do Turku' [Vihonen 1978: 91].

System przypadków morfologicznych nie pokrywa się więc z systemem przypadków syntaktycznych, za którego wzór służą Petraeusowi funkcje przypadków w łacińskiej składni. Nominativowi morfologicznemu częściowo odpowiada w opisie składniowym, oprócz obecnego nominativu, dzisiejszy translativus (cuningaxi, papixi), w niektórych wypadkach dzisiejszy essivus (surutoinna, oikena), niekiedy także współczesny adessivus (seljälläns). Za dativus uznaje dzisiejszy allativus (minulle, rascaille), a niekiedy nawet adessivus (heillä). Pod względem funkcji syntaktycznych najwięcej wykładników przyporządkowuje accusativowi. Oprócz form partitivu i genetivu w liczbie pojedynczej, mogących pełnić w języku fińskim

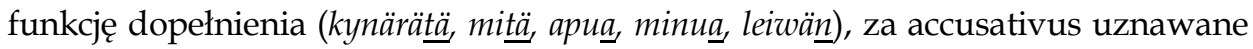
są również formy: genetivu w liczbie mnogiej (suomalaisten), illativu (wuotehen, loppuun, Turcuhun), niekiedy również translativu (jurexi), elativu (nuorudest) oraz allativu (maalle). Ablativus morfologiczny w zasadzie nie odbiega od ablativu syntaktycznego (Turgus, Turgusta, puusta, puulla, mieheldä, minulda), lecz Petraeus włącza tu zarówno obecny partitivus o znaczeniu lokatywnym (coto), jak i obecny essivus w znaczeniu lokatywnym i temporalnym. Jedynie genetivus zarówno w morfologii, jak i w składni przypomina dzisiejszy genetivus [Vihonen 1978: 180]. 
Martinius powiela wzorzec składniowy przedstawiony przez Petraeusa, rozszerzając go nieco. Mimo skrupulatnego trzymania się łacińskiego systemu przypadków, obaj gramatycy uwzględniają w opisie składniowym użycie obecnych fińskich przypadków, poza abessivem, comitativem i instructivem [Vihonen 1978: 180]. Wprawdzie formy tych trzech przypadków występują w Linguae Fennicae (miehet = 'miehettä', tietämätä, cuiwin jalgoin), jednakże według Petraeusa nie mają cech świadczących o ich przynależności do kategorii przypadka.

Trzecia gramatyka języka fińskiego, Grammatica Fennica, była dziełem Bartholda Vhaela, proboszcza w Ilmajoki, i została wydana pośmiertnie w 1733 roku w Turku (ówczesne Åbo). Podobnie jak dwie poprzednie gramatyki była to praca łacińskojęzyczna, odzwierciedlająca jeszcze w sposobie przedstawiania faktów morfologicznych antyczne wzory gramatyki [Häkkinen 1994: 105]. Grammatica Fennica zawierała już inwentarz 14 przypadków. Wprawdzie jej ujęcie nie pokrywa się całkowicie z dzisiejszym, lecz wydaje się, że Vhael dość dobrze rozumiał istotę przypadków fińskich. Poniżej przytaczam paradygmat wyrazu kala 'ryba' w liczbie pojedynczej według gramatyki Vhaela [za: Leiwo, Nieminen 2000: 418]:

Tabela 3. Inwentarz przypadków w gramatyce Vhaela [źródło: oprac. własne] ${ }^{4}$

Nazwa przypadka

Przykład

1. Nominativo

2. Genetivo

3. Dativo

4. Accusativo

5. Vocativo

6. Ablatativo

7. Locativo

8. Mediativo

9. Privativo

10. Negativo

11. Factivo

12. Nuncupativo

13. Penetrativo

14. Istructivo vel Descriptiv

\begin{tabular}{|c|}
\hline cala / piscis \\
\hline calan / piscis \\
\hline calalle / pisci \\
\hline calaa / piscem \\
\hline cala / piscis \\
\hline calasta / de, ex pisce \\
\hline calasa/in pisce \\
\hline calalla / cum pisce \\
\hline calalta / a pisce \\
\hline calatta / sine pisce \\
\hline calaxi / mutatus in piscem \\
\hline calana; calana culki / perrexit instar piscis \\
\hline calahan / in piscem; conttais calahan / repsit in piscem \\
\hline caloin \\
\hline
\end{tabular}

4 Przytaczam tu taką terminologię (np. nazwy przypadków zakończone na -vo) i skróty, jaką zawiera inwentarz przypadków Vhaela. 
Pierwszych sześć przypadków odzwierciedla łaciński model. Vhael uwzględnia jeszcze w swoim wykazie vocativus, mimo że nie ma potrzeby wyróżniania tego przypadka w języku fińskim. Dativus Vhaela reprezentuje jeden z zewnętrznych przypadków lokatywnych i odpowiada dzisiejszemu allativowi. Accusativus ma postać dzisiejszego partitivu. Nazwy przypadków, użyte przez Vhaela, różnią się od dzisiejszych. Ablativo odpowiada dzisiejszemu elativowi, locativo to obecny inessivus, mediativo - adessivus, privativo - ablativus, negativo - abessivus, factivo - translativus, nuncupativo - essivus, penetrativo - illativus, instructivo vel descriptiv - instructivus. Z dzisiejszego repertuaru przypadków brakuje jedynie comitativu. Według Kaisy Häkkinen [1994: 106] w opisie sufiksów widoczny jest wpływ gramatyki języka hebrajskiego.

Vhael nie przywiązywał wagi do podobieństwa formy poszczególnych przypadków, nie dostrzegał również symetryczności cechującej funkcje lokatywnych przypadków zewnętrznych i wewnętrznych. Nie rozumiał więc systemu przypadków lokatywnych, dzielących się pod względem formalnym i znaczeniowym na dwie grupy [Leiwo, Nieminen 2000: 418].

Pierwsze gramatyki XIX-wieczne stopniowo odchodzą od modelu łacińskiego. Na przykład gramatyka Jacoba Judéna, napisana już po szwedzku a nie po łacinie, Försök till Utredande af Finska Sprakets Grammatik (1818) zawiera inwentarz 17 przypadków. Niżej podaje przykładowy paradygmat wyrazu tuoli ‘krzesło' w liczbie pojedynczej i mnogiej [za: Wiik 1989: 19-20]:

Tabela 4. Inwentarz przypadków w gramatyce Judéna [źródło: oprac. własne]

\section{Nazwa przypadka}

1. Nominativus

2. Genetivus

3. Dativus

4. Accusativus

Partialis

5. Accusativus

Totalis

6. Vocativus

7. Ablativus

8. Locativus Inesse

\section{Liczba} pojedyncza

Liczba mnoga

\begin{tabular}{|r|r|}
\hline Tuoli & Tuolit \\
\hline Tuolin & Tuolien \\
\hline tuolille & Tuolille \\
\hline Tuolia & Tuolia \\
\hline Tuolin & Tuolit \\
\hline tuoli & Tuolit \\
\hline tuolista & tuolista \\
\hline tuolissa & tuolissa \\
\hline
\end{tabular}


Tabela 4. c.d.

\begin{tabular}{|c|c|c|}
\hline Nazwa przypadka & $\begin{array}{c}\text { Liczba } \\
\text { pojedyncza }\end{array}$ & Liczba mnoga \\
\hline 9. Locativus & tuolilla & tuolilla \\
\hline \multicolumn{3}{|l|}{ Superesse } \\
\hline 10. Possessivus & tuolilla & tuolilla \\
\hline 11. Mediativus & tuolilla & tuolilla \\
\hline 12. Privativus & tuolilta & tuolilta \\
\hline 13. Negativus & tuolita & Tuolita \\
\hline 14. Mutativus & tuoliksi & tuoliksi \\
\hline 15. Nuncupativus & tuolina & Tuolina \\
\hline 16. Penetrativus & tuoliin & Tuoliin \\
\hline 17. Descriptivus & tuolin & Tuolin \\
\hline
\end{tabular}

Pierwszych siedem przypadków powiela wzorzec łaciński, lecz nowością jest wyodrębnienie dwóch rodzajów accusativu, świadczące o tym, że Judén trafnie rozumiał istotę dopełnienia $\mathrm{w}$ języku fińskim. Accusativus partialis (cząstkowy) pełni w zdaniu funkcję dopełnienia w formie partitivu, natomiast accusativus totalis (całościowy) odpowiada dopełnieniu $\mathrm{w}$ formie genetivu $\mathrm{w}$ liczbie pojedynczej oraz formie nominativu w liczbie mnogiej. Opis ten nie odbiega od współczesnego. Allativus nadal kwalifikowany jest jako dativus, by zachować zgodność z tradycją starożytną. W spadku po wcześniejszych systematyzacjach pozostaje także vocativus. Ciekawe jest rozbicie dzisiejszego adessivu na trzy odrębne przypadki: locativus superesse tuolilla istua 'siedzieć na krześle' o znaczeniu lokatywnym, possessivus tuolilla on neljä jalkaa 'krzesło ma cztery nogi' o znaczeniu dzierżawczym oraz mediativus tuolilla lyödä 'uderzyć krzesłem' komunikujący narzędzie, którym wykonywana jest czynność [przykłady za: Wiik 1989: 21]. Jest to podział o charakterze semantycznym. W klasyfikacji Judéna po raz pierwszy zestawione zostały dwa przypadki o znaczeniu lokatywnym: locativus inesse (dzisiejszy inessivus) oraz locativus superesse (dzisiejszy adessivus). Pierwszy ma znaczenie 'znajdowanie się wewnątrz', drugi znaczenie 'znajdowanie się na zewnątrz'. Łacińskie nazwy przypadków Judéna nadal odbiegają znacznie od dzisiejszych, jednakże spośród wyróżnionych form przypadkowych brakuje jedynie comitativu. 


\section{ANNA BUNCLER}

W Finsk Grammatik wydanej w 1824 roku w Åbo (Turku) Reinhold von Becker wyróżnia 14 przypadków [za: Wiik 1989: 23-25]:

Tabela 5. Inwentarz przypadków w gramatyce von Beckera [źródło: oprac. własne]

\section{Nazwa przypadka}

1. Nominativus

2. Genitivus

3. Infinitivus

4. Accusativus

5. Instructivus

6. Caritivus eller Defectivus

7. Dativus exterior

8. Dativus interior

9. Dativus formalis

10. Locativus exterior

11. Locativus interior

12. Locativus formalis

13. Ablativus exterior

14. Ablativus interior (\& formalis)
Przykład

$\underline{\text { lintu arastaa, hevoinen juoksee }}$

linnu-n poika

siellä on lintu-ja

ampui linnu-n

mehtä lintu-ine-nsa

linnui-ta tuli metästä, hevoinen on kengi-tä linnu-lle-n, jaloi-lle-n, vei kirko-lle-n luoti sattui lintu-un, meni kirkko-on muuttuu linnu-ksi, vesi kylmettyi jää-ksi linnu-lla on poikia, pello-lla on kiviä linnu-ssa on luita lintu-na, vae sairaa-na otettiin linnu-lta, löy ruoskan jää-ltä hauli otettiin linnu-sta, linnu-sta muuttui kalaksi, lapse-sta kasvoi mieheksi)

Von Becker z reguły opatruje wyodrębnione przypadki przykładami nie pojedynczych, wyjętych z kontekstu wyrazów, lecz całych syntagm, oddających znaczenie danego przypadka. Niekiedy wskazuje również prymarną funkcję, którą określony przypadek pełni w konstrukcjach składniowych (np. nominativus - podmiotu, accusativus - dopełnienia).

Von Becker nie powiela już mechanicznie sześciu pierwszych przypadków z modelu łacińskiego, jednakże w większości pozostawia pierwotną terminologię systemu łacińskiego. Wyróżnia dzisiejszy partitivus (nazywając go infinitivem), który oddziela od accusativu (uwzględniając w nim jednak tylko formę genetywną, $\mathrm{z}$ pominięciem nominatywnej). Po raz pierwszy włącza do systemu przypadków comitativus (pod nazwą instructivu). Na szóstym miejscu umieszcza dzisiejszy abessivus (czyli caritivus, inaczej defectivus). W klasyfikacji pozostałych przypadków stosuje system trójkowy, odpowiadający dzisiejszemu podziałowi przypadków lokatywnych w języku fińskim 
na zewnętrzne (exterior), wewnętrzne (interior) oraz ogólne (formalis), które posiadały niegdyś znaczenie lokatywne, lecz je utraciły. Klasyfikację von Beckera ilustruje poniższa tabela. Brakuje w niej jedynie obecnego partitivu (w miejscu ablativus formalis), który należał do pierwotnych przypadków lokatywnych.

Tabela 6. Podział przypadków lokatywnych w gramatyce von Beckera [źródło: oprac. własne]

Exterior

\begin{tabular}{l|r|r|r|}
\hline dativus & allativus (kirko-lle- $n$ ) & illativus (kirkko-on) & translativus (linnu-ksi) \\
\cline { 2 - 4 } locativus & adessivus (linnu-lla) & inessivus (linnu-ssa) & essivus (lintu-na) \\
\hline ablativus & ablativus (linnu-lta) & elativus (linnu-sta) & \\
\cline { 2 - 4 } & &
\end{tabular}

Nazwy łacińskie - dativus, locativus i ablativus - zawierają znaczenie kierunku. Zgodnie z interpretacją łacińską dativus posiadał pierwotnie funkcję zbliżania się, locativus używany był do oznaczenia miejsca spoczynku, natomiast prymarną funkcją ablativu była zawsze funkcja oddalania się. W systemie przypadków von Beckera nie występuje ponadto dzisiejszy instructivus.

Zdaniem Kaleviego Wiika [1990], gramatyka von Beckera zapoczątkowała w fińskiej tradycji gramatycznej tzw. „okres eksperymentalistów”, kiedy to gramatycy zaczęli używać pojęcia rdzeń wyrazowy, wyróżniając rdzeń samogłoskowy i spółgłoskowy ( $\mathrm{np}$. w formach wyrazu pieni 'mały' : piene $+n$ i pien $+t a ̈)$, a ponadto zaczęli operować pojęciem sufiksu w opisie derywacji form przypadkowych. Rdzeń wyrazowy wyparł więc formę nominativu w opisach morfonologicznych ${ }^{5}$ [Leiwo, Nieminen 2000: 420].

W wydanej w 1832 roku pracy Försök till en Finsk Grammatika Matias W. Wikström nie używa specjalnej terminologii w opisie systemu przypadków, nazywając je po prostu casus. Wyodrębnia jedynie nominativus i genetivus, zaznaczając, że te same formy morfologiczne posiada również accusativus, zarówno w liczbie pojedynczej, jak i mnogiej (w obecnym opisie accusativus posiada formę genetivu jedynie w liczbie pojedynczej). Pozostałe przypadki określa jako: lle casus, lla casus, Ita casus, na casus, * $n$ casus, sa casus, sta casus, ta casus, $k s i$ casus, a (ta) casus. W jego opisie nie występują formy obecnego comitativu i instructivu [Wiik 1989: 42-50].

\footnotetext{
${ }^{5}$ Mimo to używano jeszcze nazwy 'deklinacja' w opisach wariantów rdzeni, np. w gramatyce Gustafa Renvalla z 1840 roku [Leiwo, Nieminen 2000: 420].
} 
W gramatyce Gustafa Renvalla Finsk Spraklära z 1840 roku inwentarz fińskich przypadków został ustalony w kształcie obowiązującym współcześnie. Składał się z 14 przypadków: nominativu, infinitivu (obecnego partitivu), genetivu, essivu, factivu (obecnego translativu), allativu, illativu, ablativu, elativu, adessivu, inessivu, abessivu, suffixivu (obecny comitativus) oraz adverbialu (obecny instructivus). Kolejność w uporządkowaniu przypadków odzwierciedla rozwój językoznawstwa historycznego: pierwszych pięć przypadków (nominativus, infinitivus, genetivus, essivus oraz factivus) historycznie uznawanych jest za najstarsze przypadki. Renvall przypomina o niegdysiejszym starym znaczeniu lokatywnym przypadków: factivu, infinitivu oraz essivu [Leiwo, Nieminen 2000: 419]. W Finsk Spraklära znajdujemy też ciekawe zestawienie systemów przypadków w ujęciu Renvalla, Vhaela i von Beckera [przytaczam za: Wiik 1989: 52]:

Tabela 7. Zestawienie inwentarzy przypadków w gramatykach Renvalla [1840], Vhaela [1733] oraz Beckera [1824] [źródło: oprac. własne]

\begin{tabular}{|l|r|r|r|}
\hline $\mathbf{L p}$. & Renvall, $\mathbf{1 8 4 0}$ & Vhael, $\mathbf{1 7 3 3}$ & Becker, $\mathbf{1 8 2 4}$ \\
\hline $\mathbf{1 .}$ & Nominativ. & Nominativ. & Nominativ. \\
\hline $\mathbf{2 .}$ & Infinit. & Accusativ. & Infinitiv. \\
\hline $\mathbf{3 .}$ & Genitiv. & Genitiv. & Genitiv. \\
\hline $\mathbf{4 .}$ & Essiv. & Nuncupativ. & Locativ. formalis. \\
\hline $\mathbf{5 .}$ & Factiv. & Factiv. & Dativ. formalis. \\
\hline $\mathbf{6 .}$ & Allativ. & Dativ. & Dativ. exterior. \\
\hline $\mathbf{7 .}$ & Illativ. & Penetrativ. & Dativ. interior. \\
\hline $\mathbf{8 .}$ & Ablativ. & Privativ. & Ablat. exterior. \\
\hline $\mathbf{9 .}$ & Elativ. & Ablativ. & Ablat. interior. \\
\hline $\mathbf{1 0 .}$ & Adessiv. & Mediativ. & Locativ. exterior. \\
\hline $\mathbf{1 1 .}$ & Inessiv. & Locativ. & Locat. interior. \\
\hline $\mathbf{1 2}$. & Abessiv.l. Caritiv. & Negativ. & Caritiv. \\
$\mathbf{1 3 .}$ & Suffixiv. & & Instructiv. \\
\hline $\mathbf{1 4}$ & Adverbial & Descriptiv. & \\
\hline
\end{tabular}

Konwencja opisu systemu przypadków w języku fińskim została więc w zasadzie ustalona w gramatyce Renvalla. W pracach poszczególnych gramatyków występowały co prawda jeszcze pewne różnice, na przykład Elias Lönnrot, autor Bidrag till Finska Sprakets Grammatik (1840-1841), do inwentarza przypadków włączył prolativus, który w obecnych gramatykach nie jest uznawany za przypadek, 
nie uwzględnił natomiast accusativu, jako w zasadzie nieposiadającego odrębnych wykładników morfologicznych [Häkkinen 1994: 108]. Model łaciński, jako zbyt ciasny, ewoluował w poszczególnych gramatykach w stronę morfologicznego opisu przypadka z jednym wyjątkiem - accusativu, interpretowanego nadal w wielu gramatykach XX-wiecznych na gruncie składni.

\section{Bibliografia}

BUNCLER A., 2004: Kategoria przypadka w języku fińskim, niepublikowana praca magisterska, Warszawa: Uniwersytet Warszawski.

BUNCLER A., 2012: Rozwój systemu przypadkowego w języku fińskim, „Acta Philologica" 42, s. 41-45.

HÄKKINEN K., 1994: Agricolasta nykykieleen. Suomen kirjakielen historia, Porvoo Helsinki - Juva: Werner Söderström Osakeyhtiö (WSOY).

LEIWO M., NIEMINEN L., 2000: The Finnish case system in pedagogical grammars, t. 14, Leuven-Paris-Sterling, Virginia: The History of Linguistic and Grammatical Praxis.

VIHONEN S., 1978: Suomen kielen oppikirja 1600-luvulla. Kieliopillinen ajattelu 1600luvun suomen kielen oppikirjoissa, Jyväskylä: Jyväskylän yliopisto.

VLADÁR Zs., 2003: Az ablativus a korai magyar és finn grammatikában, „Magyar nyelv" 2 (XCIX), s. 135-145.

WIIK K., 1989: Suomen kielen morfofonologian historia I. Nominien taivutus 1649-1820, Turku: Turun yliopisto, Fonetiikka.

WIIK K., 1990: Suomen kielen morfofonologian historia II. Nominien taivutus 1820-1845, Turku: Turun yliopisto, Fonetiikka. 


\section{Sijaluettelot suomen kielen ensimmäisissä kieliopeissa}

\section{(abstrakti)}

Artikkeli käsittelee sijaluettelon muodostamista suomen kielen varhaisimmissa kieliopeissa 1840-lukuun asti.

Ensimmäiset suomen kieliopit olivat Eskil Petraeuksen Langue Finnicae brevis institutio [1649] ja Matthias Martiniuksen Hodegus Finnicus, Eller Finsk Wägwijsare [1689]. Kieliopin säännöt merkitsivät Petraukselle ja Martiniukselle samaa kuin latinan kieliopin säännöt. 1600-luvun käsitysten mukaan latinan kieli ja latinan kielioppi ilmensivät logiikan yleisiä lainalaisuuksia. Sekä Petraeus, että Martinius luettelivat latinan kuusi sijaa esityksissään: nominatiivi, genetiivi, datiivi, akkusatiivi, vokatiivi ja ablatiivi. Petraeus muodosti suomen sijamuotojärjestelmän valikoimalla latinan sijoille sopivat suomalaiset merkitysvastineet. Sen takia esimerkiksi ablatiivilla oli useita loppuja: lda, ldä, sta, stä, sa, sä, lla, llä. Akkusatiivi määräytyi latinan syntaktisen funktion perusteella, eli akkusatiiveja olivat ne, joiden käännösvastineeksi sopi latinan akkusatiivi. Petrauksen paradigmasta puuttuivat seuraavat nykysijat: essiivi, translatiivi, illatiivi, abessiivi, komitatiivi ja instruktiivi, vaikka niiden muodot esiintyivät kieliopissa. Martiniuksen sijamuotojärjestelmän kuvaus mukaili, muttei kopioinut kaavamaisesti, Petrauksen esitelmää. Hän esimerkiksi tajusi sijapäätteen ja preposition tehtävien vastavuuden kielen merkitysjärjestelmässä.

Kolmas suomen kielioppi, Barthold Vhaelin Grammatica Fennica, ilmestyi 1733. Sekin oli latinankielinen, mutta siinä erotettiin jo 14 sijaa. Ensimmäiset kuusi vastasivat kuitenkin vielä latinan sijaluetteloa. Reinhold von Becker [1824] oli ensimmäinen, joka huomasi vastavuuden yleis-, sisä- ja ulkopaikallissijojen välillä. Gustav Renvallin kirjoittamassa Finsk Spraklära -kieliopissa [1840] sijaluettelo vastaa jo nykysuomen sijamuotojärjestelmää, vaikka jotkut termit ovat vielä hiukan erilaisia. 